\title{
Cadmium Effects on Mineral Accumulation and Selected Physiological and Biochemical Characters of Salix babylonica $\mathbf{L}$.
}

\author{
Jie Ouyang, Binbin Li, Chonghao Li, Xiaoshuo Shang, Jinhua Zou* \\ Tianjin Key Laboratory of Animal and Plant Resistance, College of Life Sciences, \\ Tianjin Normal University, Tianjin 300387, China
}

Received: 24 March 2017

Accepted: 10 May 2017

\begin{abstract}
To understand the phytoremediation capability of Cd by Salix babylonica L. we studied Cd accumulation and translocation, antioxidant enzyme activities, lipid peroxidation, and soluble protein contents in S. babylonica exposed to 10,50 , and $100 \mu \mathrm{M} \mathrm{Cd}$ for 7, 14, 21, and $28 \mathrm{~d}$. The results indicated that seedling growth was accelerated by $10 \mu \mathrm{M} \mathrm{Cd}$, and significantly inhibited by 50 and $100 \mu \mathrm{M} \mathrm{Cd}$. The contents of $\mathrm{Fe}$ and $\mathrm{Mn}$ decreased significantly. The superoxide dismutase (SOD) activity in roots exposed to Cd was significantly higher than that in leaves. The level of peroxidase (POD) was significantly higher than that of control except for the roots treated with 10 and $50 \mu \mathrm{M} \mathrm{Cd}$ on day 28. POD activity in leaves was lower than that in roots. The level of catalase (CAT) was significantly lower than that of control. At $100 \mu \mathrm{M} \mathrm{Cd}$, malondialdehyde (MDA) content increased significantly during the whole experiment. $50 \mu \mathrm{M} \mathrm{Cd}$ could induce high content of MDA in leaves. In general, the contents of hydrogen peroxide $\left(\mathrm{H}_{2} \mathrm{O}_{2}\right)$, superoxide anion $\left(\mathrm{O}_{2}^{--}\right)$, and soluble protein showed an increasing trend. S. babylonica could be an efficient phytoextraction plant as it had considerable ability to accumulate $\mathrm{Cd}$.
\end{abstract}

Keywords: accumulation, antioxidant enzymes, reactive oxygen species (ROS), malondialdehyde (MDA), soluble protein

\section{Introduction}

Cadmium (Cd) is thought to be one of the most toxic elements to all living organisms, even at low concentrations. In plants, $\mathrm{Cd}$ can severely influence several physiological and biochemical processes such as mineral uptake, photosynthesis, and respiration [1-2]. It has been found that $\mathrm{Cd}$ can interfere with microelements

*e-mail: zjhmon@126.com such as iron (Fe) and manganese (Mn), which leads to nutrient imbalance in plants [3].

Considerable attention has been attached to problems associated with $\mathrm{Cd}$ pollution, with rapid expansion of industrialization and the heavy use of chemical fertilizer, pesticides, and herbicides in agriculture [4]. Thus, developing efficient techniques for $\mathrm{Cd}$ removal from the environment is urgent and imperative. However, most conventional remediation approaches, such as excavation and chemical leaching of metals, are expensive and do not provide acceptable solutions to toxic metal pollution. The idea of using specific plants that hyperaccumulate 
metals to selectively remove and recycle excessive soil metals was introduced by Chaney [5]. Hyperaccumulators can accumulate several hundred-fold certain metals comparing normal plant species, with no adverse effects on their growth [6]. Plant potential for Cd extraction generally depends on shoot $\mathrm{Cd}$ concentration and shoot biomass yield [7-9]. However, hyperaccumulators are species that often have a low biomass and a slow growth rate, leading to a slow time frame for metal uptake and soil decontamination [10]. The ideal plant for metal phytoextraction should be highly productive in biomass, and assimilate and translocate to shoots a significant part of the metals. Besides, favorable characteristics such as fast growth, easy propagation, and a deep rooting system should also be needed.

The Salicaceae family with its genera Salix (willows) and Populus (poplars) comprises a large number of woody species and hybrids, of which many adapted to ecological niches such as nutrient-poor, dry, wet, or metalcontaminated environments [11-14]. Willows are known to have several characteristics that make them ideal plant species for phytoremediation application, including easy propagation and cultivation, large biomass, fast growth, deep root systems, a high transpiration rate, tolerance to hypoxic conditions, and high metal accumulation capability [15-16]. S. babylonica is a species of willow that has adapted to waterfront and wet environment with a great potential for restoration of soil environments or contaminated water, and is one of the most widely distributed and commonly cultivated willow species in China [17]. It has been reported that S. babylonica could tolerate and accumulate $\mathrm{Cd}$ at low concentration (10 $\mu \mathrm{mol} / \mathrm{L})$, and was suitable for potential phytoremediation [18-19].

Oxidative damage and ROS production can be promoted by $\mathrm{Cd}$ in the shoots and roots of plants [2021]. Oxidative stress is accelerated by the increasing production of ROS, and comprises both free radicals $\left(\mathrm{O}_{2}{ }^{-\cdot}\right.$ and $\left.\mathrm{OH} \cdot\right)$ and non-radical/molecular forms $\left(\mathrm{H}_{2} \mathrm{O}_{2}\right.$ and singlet oxygen) [22]. At a certain level, ROS plays an important role as signaling molecules in regulation of biological process and influences the activity of enzymes [23]. The ROS at higher concentrations are harmful to plants. For maintaining the compatible level of ROS, plants run defensive system (SOD, POD, and CAT) to scavenge ROS [24].

$\mathrm{O}_{2}-{ }^{-}$and $\mathrm{H}_{2} \mathrm{O}_{2}$ are important ROSs that cause damages to cellular plasma membrane lipids and other biomolecules [25]. It is essential to prevent oxidative damage by detoxificating $\mathrm{O}_{2} \cdot-$ and $\mathrm{H}_{2} \mathrm{O}_{2}$. SOD, as the major $\mathrm{O}_{2} \cdot-$ scavenging enzyme, catalyzes the disproportionation of $\mathrm{O}_{2}$ - radicals into $\mathrm{H}_{2} \mathrm{O}_{2}$ and $\mathrm{O}_{2}$ in the cytosol, chloroplasts, and mitochondria, and it is usually considered as the first line of antioxidant defense systems, while both CAT and POD catalyze the degradation of $\mathrm{H}_{2} \mathrm{O}_{2}$ to $\mathrm{H}_{2} \mathrm{O}$ and $\mathrm{O}_{2}$ [2627]. Generally, these enzymes play a cooperative role in protecting plants. MDA content is generally used as an indicator of oxidative damage to lipid peroxidation [28]. The content of soluble protein in plants exposed to Cd is changed, which plays an important role in avoiding harmful stress. There are several reports about the changes of soluble protein under Cd stress [29-31].

In order to better understand tolerant mechanisms under $\mathrm{Cd}$ stress in woody plants we investigated the effects of $\mathrm{Cd}$ on growth, $\mathrm{Cd}$ accumulation, and its effects on other mineral accumulation, antioxidant enzymes, MDA content, oxidative stress, and antioxidative response of $S$. babylonica plants under Cd stress.

\section{Experimental}

\section{Culture Conditions and Cadmium Treatment}

Healthy and equal-sized woody cuttings ( $20 \mathrm{~cm}$ long) from shoots of $S$. babylonica grown in the campus of Tianjin Normal University, Tianjin, China were collected and fully rinsed with distilled water before starting the experiment. They were germinated in distilled water in plastic containers for two weeks. Then the plants were grown in containers with 6 L half-strength Hoagland's solution for a week. The solution $(\mathrm{pH} 5.5)$ consisted of $5 \mathrm{mM} \mathrm{KNO}, 5 \mathrm{mM} \mathrm{Ca}\left(\mathrm{NO}_{3}\right)_{2}, 1 \mathrm{mM} \mathrm{KH}_{2} \mathrm{PO}_{4}, 50 \mu \mathrm{M}$ $\mathrm{H}_{3} \mathrm{BO}_{3}, 10 \mu \mathrm{M}$ FeEDTA, $4.5 \mu \mathrm{M} \mathrm{MnCl}_{2}, 3.8 \mu \mathrm{M} \mathrm{ZnSO}_{4}$, $0.3 \mu \mathrm{M} \mathrm{CuSO}_{4}$, and $0.1 \mu \mathrm{M}\left(\mathrm{NH}_{4}\right)_{6} \mathrm{Mo}_{7} \mathrm{O}_{24}$. The plants were randomly divided into four groups. Control groups were grown in the solution and the other three groups were treated with three different $\mathrm{Cd}$ concentrations of 10 , 50, and $100 \mu \mathrm{M} \mathrm{CdCl}_{2}$ solutions for $28 \mathrm{~d}$. Cd was provided as cadmium chloride $\left(\mathrm{CdCl}_{2}\right)$. The solutions were continuously aerated with an aquarium air pump every day.

\section{Plant Harvest}

The plants were harvested respectively on days 7,14 , 21, and 28. Root length and shoot length were measured. At the time of harvest, the plants exposed to $0,10,50$, and $100 \mu \mathrm{M} \mathrm{Cd}$ were washed thrice with distilled water and finally with deionized water. The intact plants were divided into roots and leaves for further analysis. New Hoagland's solution and different concentrations of $\mathrm{Cd}$ solutions were added to the remaining plants after harvest.

\section{Determining $\mathrm{Cd}$ and Other Minerals}

Plants exposed to 10,50 , and $100 \mu \mathrm{M} \mathrm{Cd}$ solutions for $28 \mathrm{~d}$ and control were harvested respectively based on uniformity of size and color (removing the greatest and the smallest plants and then selected randomly). The plants were washed thoroughly with running tap water, and then with deionized water. After removal of necrotic and putrid tissue, the roots were immersed in $20 \mathrm{mM}$ EDTA-Na for $15 \mathrm{~min}$ and rinsed in tap water and deionized water to remove traces of nutrients and $\mathrm{Cd}$ ions from the root surfaces. The plants were divided into roots and shoots (leaves, new stems, and old stems). They were dried at 
$45^{\circ} \mathrm{C}$ for $72 \mathrm{~h}, 80^{\circ} \mathrm{C}$ for $48 \mathrm{~h}$, and $105^{\circ} \mathrm{C}$ for $12 \mathrm{~h}$, and then ground with a cutting mill (IKA-Werke GMBH \& CO. $\mathrm{KG}$, Germany). All dried plant samples were prepared using the wet-digestion method [32]. Concentrations of $\mathrm{Cd}, \mathrm{Mn}$, and $\mathrm{Fe}$ were analyzed using an atomic absorption spectrometer (PerkinElmer AAnalyst 400, USA).

\section{Examining Antioxidant Enzyme Activities}

The fresh roots $(0.05 \mathrm{~g})$ and leaves $(0.1 \mathrm{~g})$ of $S$. babylonica from each treatment were harvested at the end of each time interval $(7 \mathrm{~d})$, and were homogenized in a mortar and pestle with $0.05 \mathrm{M}$ sodium phosphate buffer (PBS, pH 7.8). The homogenate was centrifuged at 12,000 rpm for $10 \mathrm{~min}$ and the supernatant liquid was used for analyzing SOD, POD, and CAT. All above steps were carried out at $4^{\circ} \mathrm{C}$.

The activities of SOD, POD, and CAT were determined by the method of Qin et al. [33], and absorbance was recorded (UV/VIS Spectrometer Lambda 35, PerkinElmer, USA).

\section{Determining $\mathrm{H}_{2} \mathrm{O}_{2}$}

Hydrogen peroxide $\left(\mathrm{H}_{2} \mathrm{O}_{2}\right)$ content in S. babylonica leaves and roots were estimated according to the method of $\mathrm{Hu}$ et al. [34], with some modifications. At the end of each time interval ( $7 \mathrm{~d}$ ) of the $\mathrm{Cd}$ treatment, the fresh leaves $(0.5 \mathrm{~g})$ or roots $(0.5 \mathrm{~g})$ were harvested and homogenized in a pestle and mortar with $5 \mathrm{~mL}$ cold acetone $\left(-20^{\circ} \mathrm{C}\right)$ and centrifuged at $12,000 \mathrm{rpm}$ at $4^{\circ} \mathrm{C}$ for $10 \mathrm{~min}$. One milliliter of supernatant extracts was mixed thoroughly with $0.15 \mathrm{~mL}$ of $5 \%$ titanium sulfate and $0.2 \mathrm{~mL}$ of ammonia, and the reaction mixture was then centrifuged at $12,000 \mathrm{rpm}$ at $4^{\circ} \mathrm{C}$ for $10 \mathrm{~min}$. Five milliliters of $2 \mathrm{M} \mathrm{H}_{2} \mathrm{SO}_{4}$ was added to dissolve the yellow precipitate. The absorbance of the yellow color solution was measured at $415 \mathrm{~nm}$. The level of $\mathrm{H}_{2} \mathrm{O}_{2}$ was calculated from a standard curve generated with known concentrations of $\mathrm{H}_{2} \mathrm{O}_{2}$. The $\mathrm{H}_{2} \mathrm{O}_{2}$ content was expressed as $\mu \mathrm{mol}$ per $\mathrm{g}$ of fresh weight.

\section{Determining $\mathrm{O}_{2}{ }^{--}$}

Superoxide anion $\left(\mathrm{O}_{2}^{-}\right)$assay was according to the method of Zhou et al. [35], with some modifications. The fresh leaves $(0.2 \mathrm{~g})$ and roots $(0.2 \mathrm{~g})$ were homogenized in a pestle and mortar with $2 \mathrm{~mL} 0.05 \mathrm{M}$ PBS ( $\mathrm{pH} 7.8$ ). The homogenate was centrifuged at $12,000 \mathrm{rpm}$ at $4^{\circ} \mathrm{C}$ for $10 \mathrm{~min} .0 .5 \mathrm{~mL}$ supernatant extract was mixed thoroughly with $0.5 \mathrm{~mL}$ of $0.05 \mathrm{M}$ PBS and $1 \mathrm{~mL}$ hydroxylamine hydrochloride at $25^{\circ} \mathrm{C}$ for $20 \mathrm{~min} .1 \mathrm{~mL}$ of $17 \mathrm{mM}$ sulfanilic acid and $1 \mathrm{~mL}$ of $7 \mathrm{mM}$ alpha-Naphthylamine were added to the mixed solution for another $20 \mathrm{~min}$ at $25^{\circ} \mathrm{C}$. After the same volume $(4 \mathrm{~mL})$ of trichloromethane was added to the solution, the pink supernatant was measured at $530 \mathrm{~nm}$. The $\mathrm{O}_{2} \cdot$ - content was expressed as $\mu \mathrm{mol}$ per $\mathrm{g}$ of fresh weight.

\section{Measurement of MDA Content}

The level of lipid peroxidation was expressed as the content of MDA according to Qin et al. [33]. The roots $(0.15 \mathrm{~g})$ and leaves $(0.15 \mathrm{~g})$ from each treatment were

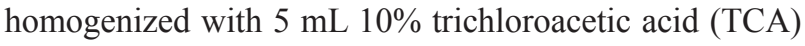
with a pestle and mortar at the end of each time interval (7 d). Homogenates were centrifuged at 12,000 rpm at $4^{\circ} \mathrm{C}$ for $10 \mathrm{~min} .2 \mathrm{~mL}$ of $0.6 \%$ 2-thiobarbituric acid (TBA) in $10 \%$ TCA was added to each $2 \mathrm{~mL}$ aliquot of the supernatant. The mixtures were heated in boiled water for $15 \mathrm{~min}$ and then quickly cooled in an ice bath. After centrifuging at 5,000 rpm for $10 \mathrm{~min}$ the absorbance of the supernatant was recorded at $532 \mathrm{~nm}$ and $450 \mathrm{~nm}$. Lipid peroxidation was expressed as the MDA content in nmol per $g$ of fresh weight.

\section{Determining Soluble Protein Content}

Measuring soluble protein content in this investigation was carried out according to Bradford's [36] method
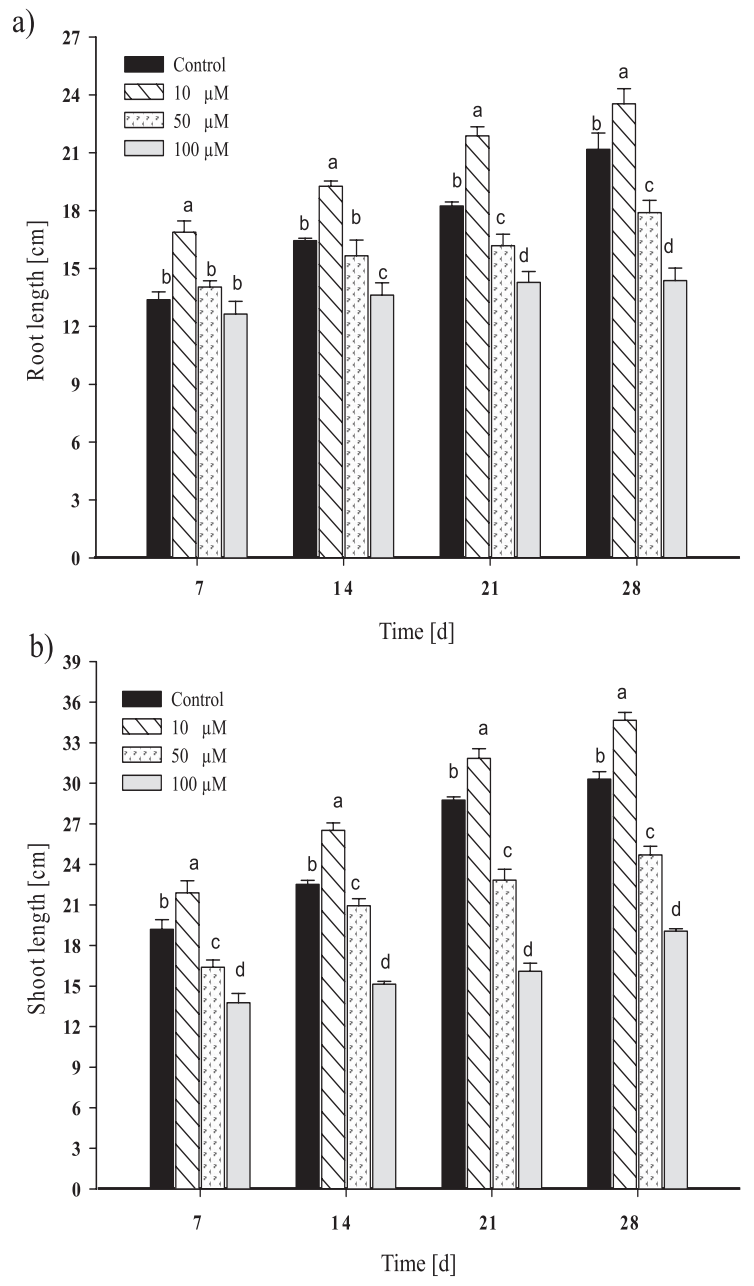

Fig. 1. Effects of different Cd concentrations on root and shoot length of Salix babylonica exposed to Cd stress for $28 \mathrm{~d}$. a) root length, b) shoot length. Vertical bars denote SE and values with different letters differ significantly from each other $(P<0.05$, $t$-test). 
Table 1. Cd, Fe, and Mn concentrations of different organs in S. babylonica under Cd stress for $28 \mathrm{~d}$.

\begin{tabular}{|c|c|c|c|c|}
\hline \multicolumn{5}{|c|}{$\mu \mathrm{g} / \mathrm{g}$ dry weight $\pm \mathrm{SE}$} \\
\hline \multirow{2}{*}{ Treatment $(\mu \mathrm{M})$} & \multirow{2}{*}{ Organs } & \multicolumn{3}{|c|}{ Element } \\
\hline & & $\mathrm{Cd}$ & $\mathrm{Fe}$ & $\mathrm{Mn}$ \\
\hline Control & \multirow{4}{*}{ Roots } & $0.00 \pm 0.00 \mathrm{a}$ & $584.88 \pm 0.33 \mathrm{a}$ & $401.25 \pm 0.07 \mathrm{a}$ \\
\hline 10 & & $898.79 \pm 1.30 \mathrm{~b}$ & $501.41 \pm 0.32 b$ & $123.47 \pm 0.16 b$ \\
\hline 50 & & $1027.16 \pm 1.12 \mathrm{c}$ & $411.13 \pm 0.71 \mathrm{c}$ & $50.41 \pm 0.52 \mathrm{c}$ \\
\hline 100 & & $1069.78 \pm 0.46 \mathrm{~d}$ & $399.19 \pm 2.92 d$ & $34.69 \pm 0.94 d$ \\
\hline Control & \multirow{4}{*}{ Shoots } & $0.00 \pm 0.00 \mathrm{a}$ & $530.88 \pm 1.19 a$ & $172.75 \pm 0.19 a$ \\
\hline 10 & & $241.00 \pm 1.01 \mathrm{~b}$ & $379.21 \pm 0.81 b$ & $90.33 \pm 0.41 b$ \\
\hline 50 & & $688.33 \pm 1.26 \mathrm{c}$ & $328.45 \pm 1.02 \mathrm{c}$ & $87.21 \pm 1.27 \mathrm{c}$ \\
\hline 100 & & $1070.33 \pm 2.90 \mathrm{~d}$ & $277.58 \pm 1.00 \mathrm{~d}$ & $77.25 \pm 0.13 \mathrm{~d}$ \\
\hline
\end{tabular}

Values followed by different letters differ significantly from each other $(P<0.05)$. Means \pm SE, $\mathrm{n}=6$

using bovine serum albumin (BSA) as a standard. The fresh roots $(0.05 \mathrm{~g})$ and leaves $(0.1 \mathrm{~g})$ from each treatment were washed with distilled water and homogenized in a mortar and pestle with $5 \mathrm{~mL} 0.05 \mathrm{M}$ PBS (pH 7.8) at the end of each time interval $(7 \mathrm{~d})$ of the $\mathrm{Cd}$ treatment. The homogenate was centri-fuged at $12,000 \mathrm{rpm}$ for $10 \mathrm{~min}$ and the absorbance of $0.1 \mathrm{~mL}$ supernatant mixed with $3 \mathrm{~mL}$ Coomassie Brilliant Blue G-250 reagent recorded at $595 \mathrm{~nm}$ after $6 \mathrm{~min}$, and was used for analyzing soluble protein content. The soluble protein content was expressed as mg per $\mathrm{g}$ of fresh weight.

\section{Statistical Analysis}

Each treatment was replicated five times for statistical validity. Statistical analysis was performed with statistical package SPSS (version 17.0). Data were tested at a significance level of $P<0.05$ by one-way analysis of variance (ANOVA) completed with $t$-test.

\section{Results}

\section{Effects of Cd on Seedling Growth}

The effects of $\mathrm{Cd}$ on root and shoot growth of $S$. babylonica varied with concentration and treatment time (Fig. 1). Root length increased significantly $(P<0.05)$ at $10 \mu \mathrm{M} \mathrm{Cd}$ during the whole experiment in comparison with control and the other treatment groups. 50-100 $\mu \mathrm{M}$ $\mathrm{Cd}$ showed the significantly inhibitory effect during the 14-28 d period treatment, except for the group exposed to $50 \mu \mathrm{M} \mathrm{Cd}$ on day 14 when compared with control (Fig. 1a). At $100 \mu \mathrm{M} \mathrm{Cd}$, root growth was inhibited severely and stopped completely. Shoot length was exposed to 50 and $100 \mu \mathrm{M} C d$ decreased significantly $(P<0.05)$ during the whole experiment time when compared with control (Fig. 1b). $10 \mu \mathrm{M} \mathrm{Cd}$ played a significant role in promoting shoot growth in comparison with control $(P<0.05)$.

\section{Cadmium Accumulation and its Effects on Other Minerals}

Statistical analysis showed the presence of significant correlations between the concentration of $\mathrm{Cd}$ and microelements ( $\mathrm{Fe}$ and $\mathrm{Mn}$ ). The accumulation of $\mathrm{Cd}$ in $S$. babylonica roots and shoots varied with $\mathrm{Cd}$ concentration. The $\mathrm{Cd}$ content of the roots and shoots increased with increasing $\mathrm{Cd}$ concentration (Table 1). At low $\mathrm{Cd}$ concentration $(10 \mu \mathrm{M}), \mathrm{Cd}$ ions primarily accumulated in roots, and small amounts of $\mathrm{Cd}$ were transported to shoots. At high $\mathrm{Cd}$ concentration $(100 \mu \mathrm{M})$ there was no obvious difference between roots and shoots. In the presence of $\mathrm{Cd}$, the contents of $\mathrm{Fe}$ and $\mathrm{Mn}$ in roots and shoots of $S$. babylonica decreased significantly $(P<0.05)$ with increasing $\mathrm{Cd}$ concentration.

\section{Effects of Cd on Activities of Antioxidant Enzymes}

The changes of antioxidant enzyme activities (SOD, POD, and CAT) in $S$. babylonica roots and leaves exposed to $\mathrm{Cd}$ at different concentrations were presented in Fig. 2. In roots the SOD activity exposed to 10 and $50 \mu \mathrm{M}$ Cd was significantly high $(P<0.05)$ during the whole experiment time when compared with control and $100 \mu \mathrm{M} \mathrm{Cd}$ treatment (Fig. 2a). There was no obvious change in activity between control and the $100 \mu \mathrm{M} \mathrm{Cd}$ treatment during $21-\mathrm{d}$ period of treatment. The activity of SOD in roots exposed to $100 \mu \mathrm{M}$ Cd on day 28 was lower than control. In leaves, SOD activity of all Cd treatments was significantly higher than that of control during the 28-d period $(P<0.05)$ (Fig. 2b). SOD activity increased with increasing $\mathrm{Cd}$ concentration and prolonged treatment time during the 21-d experiment and declined sharply at day 28. Both controls and Cd treatments showed higher SOD activity in roots than in leaves. The effects of $\mathrm{Cd}$ on POD activities of $S$. babylonica roots and leaves varied 
with the different $\mathrm{Cd}$ concentrations and the duration of treatment. The POD activity in roots exposed to all $\mathrm{Cd}$ concentrations was significant $(P<0.05)$ during the whole experiment except for the groups treated with 10 and $50 \mu \mathrm{M} \mathrm{Cd}$ on day 28 (Fig. 2c). Cd induced significantly high POD activity in leaves during the whole $\mathrm{Cd}$ period treatment in comparison with control (Fig. 2d). The POD activity in leaves was lower than that in roots. The CAT activities in roots and leaves of $S$. babylonica were present in Figs 2(e-f). The activities of CAT in roots and leaves exposed to $\mathrm{Cd}$ decreased significantly $(P<0.05)$ during the 28-d treatment when compared with control. Both controls and $\mathrm{Cd}$ treatments showed higher CAT activity in leaves than in roots.

$$
\text { Effects of } \mathrm{Cd} \text { on } \mathrm{H}_{2} \mathrm{O}_{2} \text { and } \mathrm{O}_{2} \cdot-\text { Content }
$$

Information on $\mathrm{H}_{2} \mathrm{O}_{2}$ and $\mathrm{O}_{2}$-- contents of S. babylonica stressed by $\mathrm{Cd}$ is shown in Figs 3-4. In roots the $\mathrm{H}_{2} \mathrm{O}_{2}$ contents in all $\mathrm{Cd}$ treatments were significantly higher a)

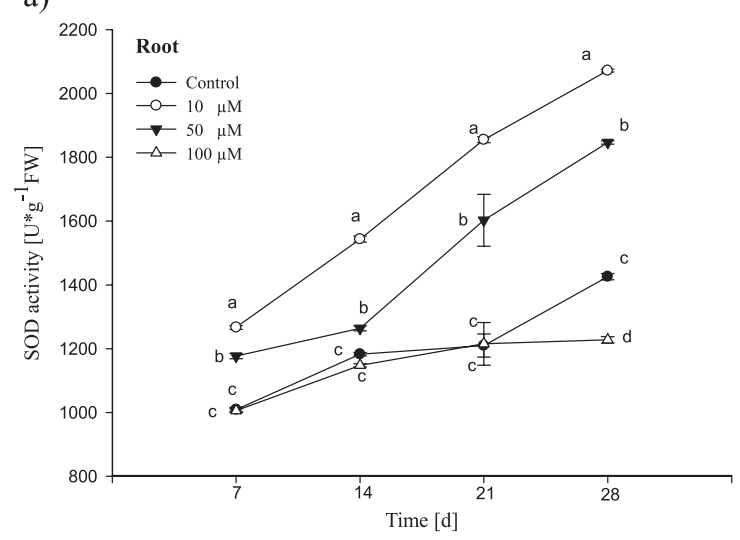

c)

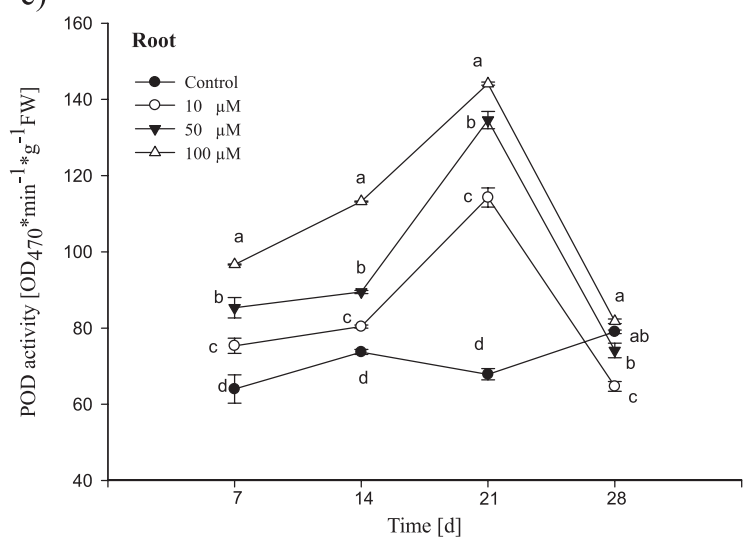

e)

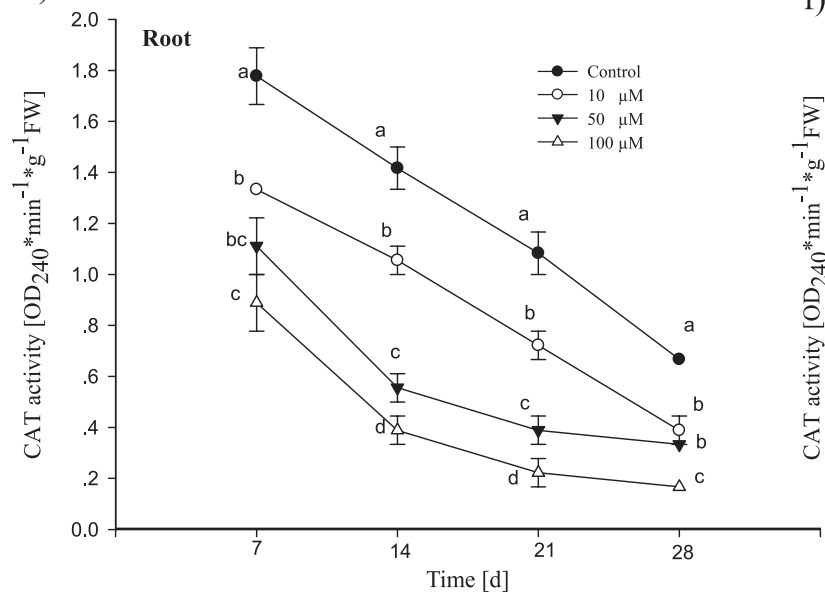

b)

f)

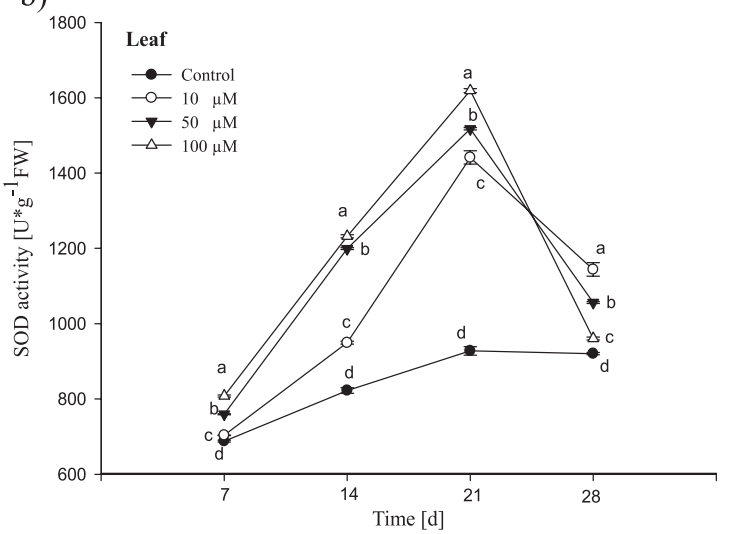

d)
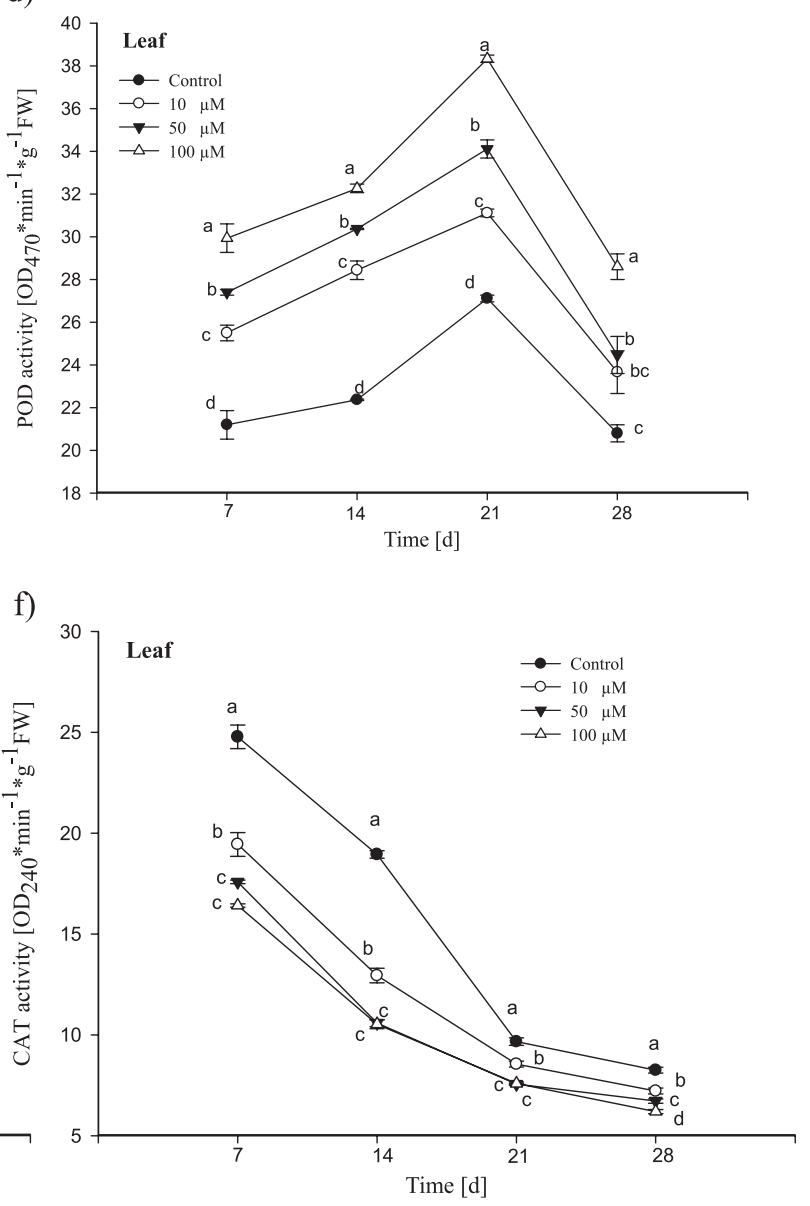

Fig. 2. Effects of different Cd concentrations on the activities of three antioxidant enzymes in Salix babylonica exposed to Cd stress for 28 d. a) SOD in roots, b) SOD in leaves, c) POD in roots, d) POD in leaves, e) CAT in roots, f) CAT in leaves. Vertical bars denote SE and values with different letters differ significantly from each other $(P<0.05, t$-test). 
$(P<0.05)$ during the whole experiment than that in control, except for the group exposed to $10 \mu \mathrm{M} \mathrm{Cd}$ on days 7 and 28 (Fig. 3a). The contents of $\mathrm{H}_{2} \mathrm{O}_{2}$ in leaves increased significantly $(P<0.05)$ with increasing $\mathrm{Cd}$ concentration and prolonged treatment time, except for the group treated with $10 \mu \mathrm{M} \mathrm{Cd}$ on days 21 and 28 (Fig. 3b). The $\mathrm{O}_{2}{ }^{--}$contents in roots exposed to $\mathrm{Cd}$ increased significantly $(P<0.05)$ in comparison with control during the 28-d treatment (Fig. 4a). In leaves, the $\mathrm{O}_{2}{ }^{--}$contents rose significantly $(P<0.05)$ during days 14 and 21 when compared with control (Fig. 4b). There were no obvious changes in the $\mathrm{O}_{2}{ }^{--}$contents of leaves exposed to $\mathrm{Cd}$ except for the groups treated with $100 \mu \mathrm{M} \mathrm{Cd}$ on days 7 and 28 .

\section{Effects of Cd on Lipid Peroxidation}

The effects of Cd on MDA contents of S. babylonica are presented in Fig. 5. The MDA contents in roots exposed to $100 \mu \mathrm{M} \mathrm{Cd}$ are significantly high $(P<0.05)$ during the whole experiment when compared with control
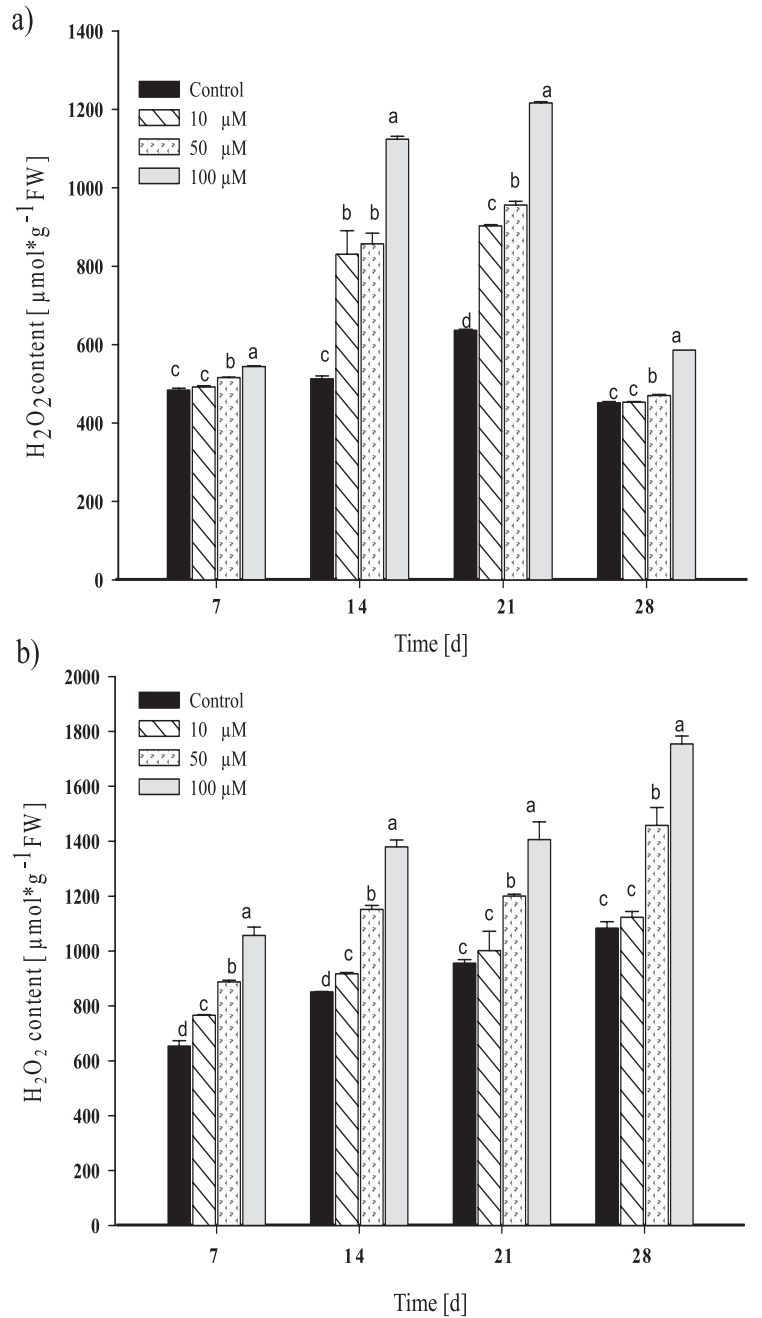

Fig. 3. Effects of different $\mathrm{Cd}$ concentrations on the $\mathrm{H}_{2} \mathrm{O}_{2}$ contents in Salix babylonica exposed to Cd stress for 28 d. a) $\mathrm{H}_{2} \mathrm{O}_{2}$ content in roots, b) $\mathrm{H}_{2} \mathrm{O}_{2}$ content in leaves. Vertical bars denote SE and values with different letters differ significantly from each other $(P<0.05, t$-test $)$. and the other treatment groups (Fig. 5a). There were no obvious differences in root MDA contents between control and the 10 and $50 \mu \mathrm{M} \mathrm{Cd}$ treatment groups. Data from Fig. 5b) revealed that 50 and $100 \mu \mathrm{M} \mathrm{Cd}$ could raise MDA content significantly $(P<0.05)$ in leaves when compared with control and other treatment groups during the whole experiment. $10 \mu \mathrm{M}$ Cd had no obvious effects on MDA content during the whole experiment in comparison with control.

\section{Effects of Cd on Soluble Protein Contents}

The effects of $\mathrm{Cd}$ on soluble protein contents are presented in Fig. 6. Soluble protein contents of roots and leaves varied with different $\mathrm{Cd}$ concentrations. The content of soluble protein in roots exposed to $50 \mu \mathrm{M}$ $\mathrm{Cd}$ was the highest among all the groups (Fig. 6a). The soluble protein contents in roots of all $\mathrm{Cd}$ treatments were significantly higher $(P<0.05)$ than that in control during the whole 28 -d period (Fig. 6a), and the contents
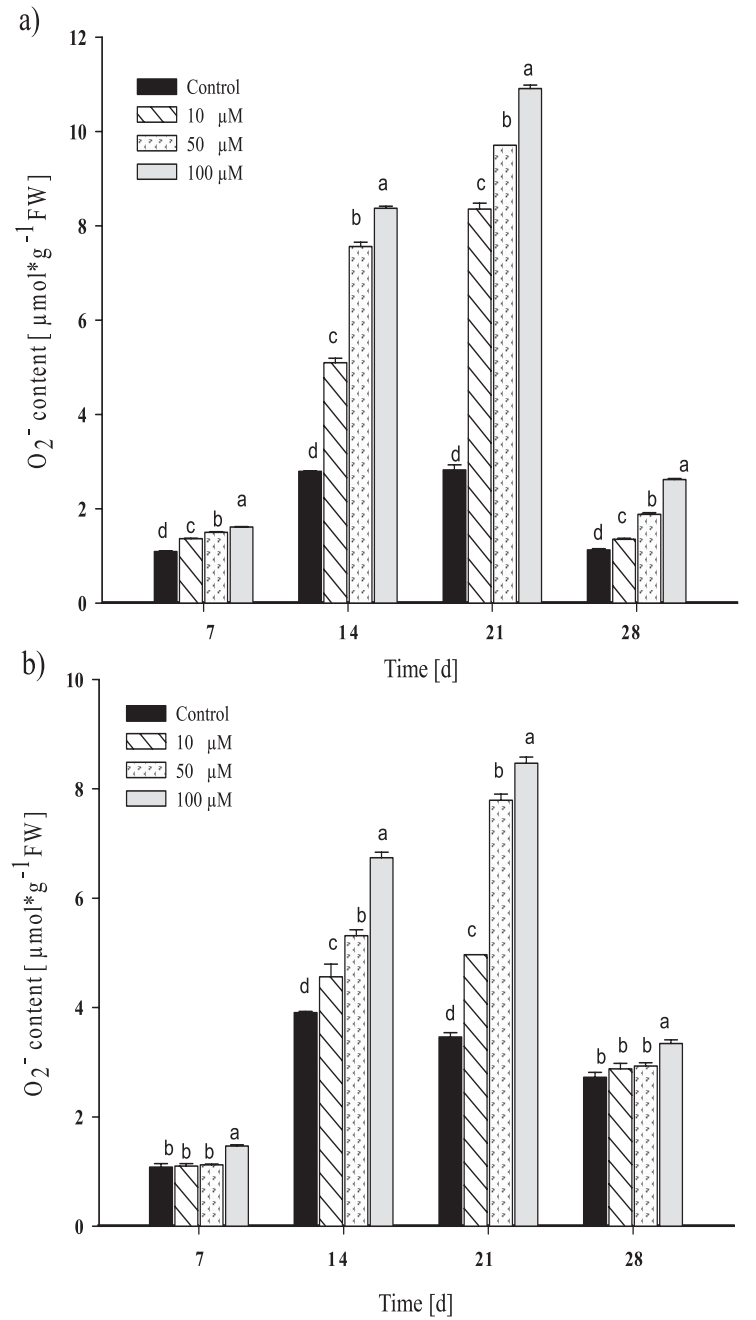

Fig. 4. Effects of different $\mathrm{Cd}$ concentrations on the $\mathrm{O}_{2} \cdot-$ content in Salix babylonica exposed to Cd stress for 28 d. a) $\mathrm{O}_{2} \cdot-$ content in roots, b) $\mathrm{O}_{2}{ }^{--}$content in leaves. Vertical bars denote $\mathrm{SE}$ and values with different letters differ significantly from each other $(P<0.05, t$-test $)$. 
of soluble protein in leaves exposed to all $\mathrm{Cd}$ treatment concentrations increased significantly $(P<0.05)$ during the 21-d treatment period, except for the $10 \mu \mathrm{M}$ Cd group on days 7 and 21 (Fig. 6b).

\section{Discussion}

The results in the present investigation show that during the whole experiment $\mathrm{Cd}$ accelerated plant growth of $S$. babylonica significantly $(P<0.05)$ at $10 \mu \mathrm{M}$ concentration, and 50 and $100 \mu \mathrm{M} \mathrm{Cd}$ had significantly inhibitory effects $(P<0.05)$. This is in agreement with the findings of Yang and Chen [18].

There have been many reports since then on the use of some crop plants and forest species (including poplar and willows) to remove $\mathrm{Cd}$ from contaminated soils [4, 10, 25, 37-40]. It has been reported that a few clones of willows have high heavy metal tolerance [13-14, 41]. Plants growing on heavy metal-contaminated soils had to develop
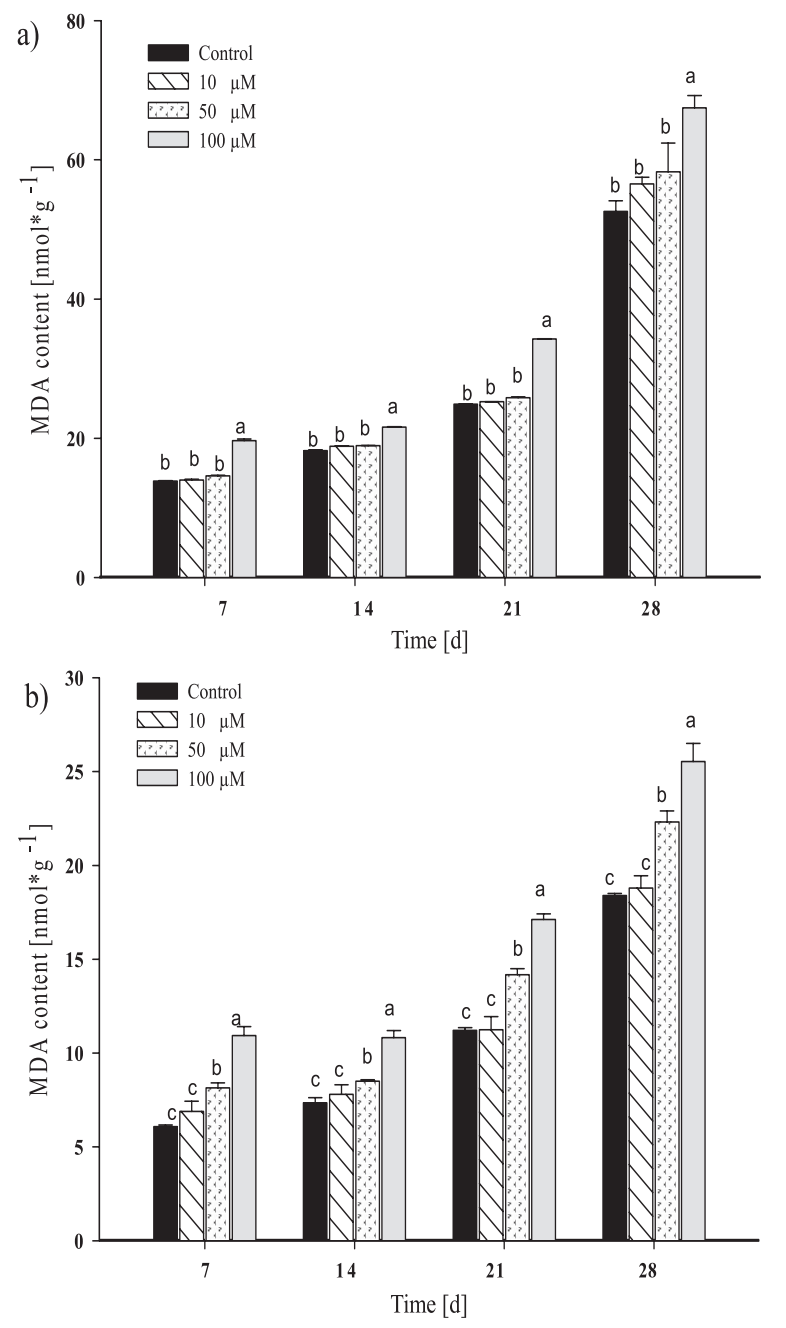

Fig. 5. Effects of different Cd concentrations on the MDA content in Salix babylonica exposed to Cd stress for $28 \mathrm{~d}$. a)MDA content in roots, b) MDA content in leaves. Vertical bars denote $\mathrm{SE}$ and values with different letters differ significantly from each other $(P<0.05, t$-test $)$. adaptation strategies requiring complex alterations in the plant metal homeostasis network, including metal uptake, chelation, transport, storage, biochemical detoxification, and tolerance [42]. Data from the present investigation showed that $S$. babylonica had the ability to accumulate $\mathrm{Cd}$ primarily in their roots $(79 \%)$ at low Cd concentration $(10 \mu \mathrm{M})$ with lower concentrations in the shoots, while at high $\mathrm{Cd}$ concentration $(100 \mu \mathrm{M}) \mathrm{Cd}$ accumulation was more or less the same between roots and shoots. There were several definitions on hyperaccumulators $[9,42]$. Most recognized standard criteria were based on metal concentrations in aboveground tissue of plant material sampled from its natural habitat [4]. According to the currently accepted shoot concentration defining hyperaccumulation being $0.01 \%(\mathrm{w} / \mathrm{w})$ for $\mathrm{Cd}$ [8], $S$. babylonica could be considered an efficient phytoextraction plant with considerable ability to accumulate $\mathrm{Cd}$. This was in accordance with the findings of Dos Santos Utmazian and Wenzel [41], Yang and Chen [18], Wang et al. [19], and Ling et al. [39]. But its
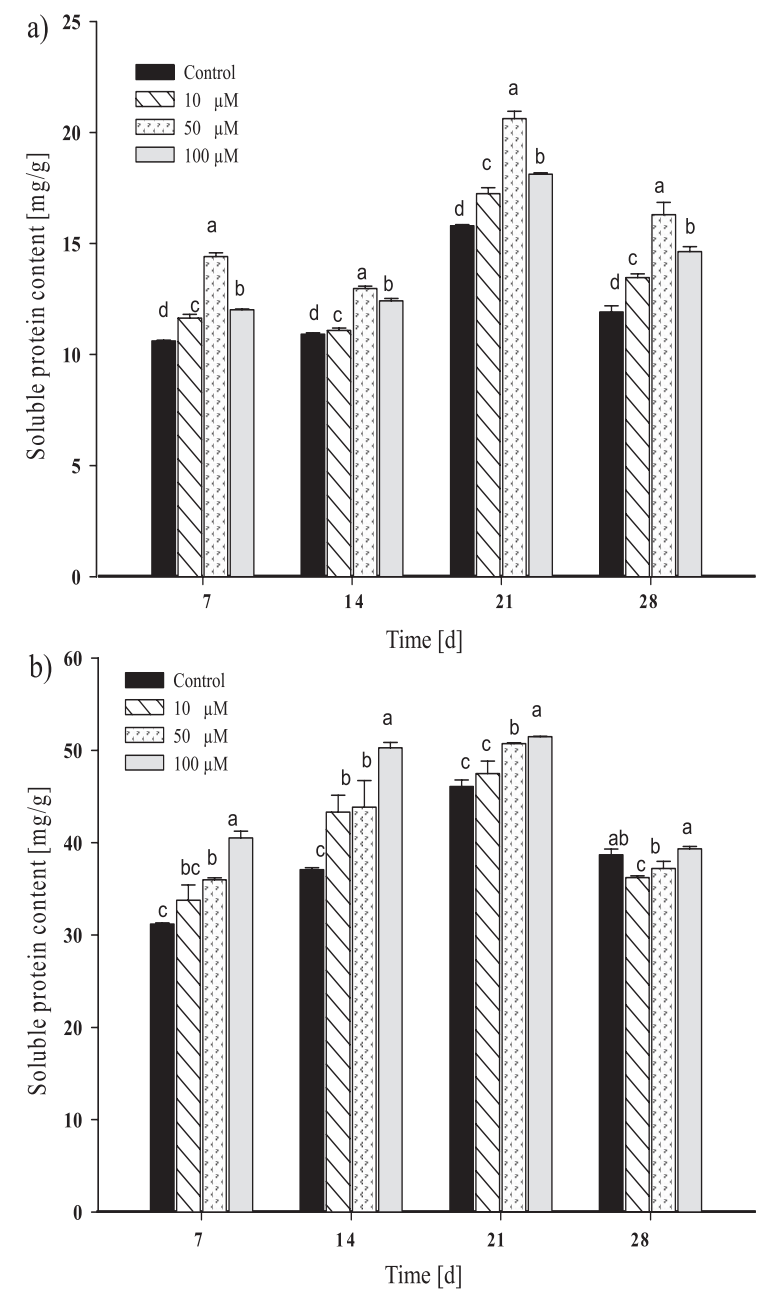

Fig. 6. Effects of different $\mathrm{Cd}$ concentrations on the soluble protein content in Salix babylonica exposed to Cd stress for $28 \mathrm{~d}$. a) soluble protein content in roots, b) soluble protein content in leaves. Vertical bars denote SE and values with different letters differ significantly from each other $(P<0.05, t$-test $)$. 
accumulating $\mathrm{Cd}$ ability was low when compared with Salix smithiana, Salix dasyclados, and Salix matsudana [14, 19, 39, 41, 43].

$\mathrm{Fe}$ and Mn play a vital role in mitigating $\mathrm{Cd}$ stress on plants by activating certain $\mathrm{Cd}$ avoidance and/or tolerance mechanisms in plants [43-46]. The results in the present investigation indicated that in the presence of $\mathrm{Cd}$ and the contents of $\mathrm{Mn}$ and $\mathrm{Fe}$ in roots and shoots of $S$. babylonica decreased significantly $(P<0.05)$ with increasing $\mathrm{Cd}$ concentrations during the whole treatment period. Some research has indicated that Fe and Mn were conducive to internal defensive mechanisms in plants [3]. The two elements compete with $\mathrm{Cd}$ in the active transporters and can minimize $\mathrm{Cd}$ transportation into plants. So the concentrations of $\mathrm{Fe}$ and $\mathrm{Mn}$, and $\mathrm{Cd}$ levels in the seedlings showed a negative correlation during the whole experiment. This may explain why concentrations of $\mathrm{Fe}$ and $\mathrm{Mn}$ gradually declined with increased $\mathrm{Cd}$ concentrations in the seedlings. Adding $\mathrm{Mn}$ to the solution containing $\mathrm{Cd}$ can significantly improve plant growth and reduced the concentrations of $\mathrm{Cd}$ in all organs of the plant [47]. Evidence from Kovács et al.'s work [48] demonstrated that $\mathrm{Fe}$ ions might compete with $\mathrm{Cd}$ ions for the same membrane binding (transport) sites in plants. Adding an adequate $\mathrm{Fe}$ ion to plants exposed to $\mathrm{Cd}$ can result in increased activity of antioxidative enzymes against oxidative stress [20].

Plants possess a number of antioxidant systems that protect them from oxidative damage [49]. These defensive systems are composed of enzymatic scavengers of activated oxygen such as SOD, POD, and CAT [50]. Data from the investigation showed that the SOD activities in the leaves of $S$. babylonica exposed to all the $\mathrm{Cd}$ treatments and in the roots exposed to 10 and $50 \mu \mathrm{M} \mathrm{Cd}$ were significantly higher $(P<0.05)$ than those in controls. High SOD activity has been associated with stress tolerance in plants, which may be attributed to the increased production of superoxide, resulting in the activation of existing enzyme pools or increased expression of genes encoding SOD [50]. The activity of SOD in the roots exposed to $100 \mu \mathrm{M}$ Cd was significantly lower $(P<0.05)$ compared to control in the present investigation, suggesting that reduced SOD might be due to an inactivation of the enzyme by $\mathrm{H}_{2} \mathrm{O}_{2}$ produced in different compartments, where SOD catalyzes the disproportionation of superoxide radicals [51]. POD is also an important enzyme that is able to scavenge $\mathrm{H}_{2} \mathrm{O}_{2}$, which is a major substance degraded by SOD. The activity of POD in $S$. babylonica increased significantly $(P<0.05)$ except for the roots treated with 10 and $50 \mu \mathrm{M} \mathrm{Cd}$ and the leaves exposed to $10 \mu \mathrm{M} \mathrm{Cd}$ at day 28 in comparison with controls in the present investigation. Increased POD activity might be due to $\mathrm{Cd}$ directly causing excessive production of $\mathrm{H}_{2} \mathrm{O}_{2}$ in plants. Thus, increased POD activity, in turn, scavenged excessive $\mathrm{H}_{2} \mathrm{O}_{2}$ and damage was limited [4]. CAT is an antioxidant enzyme that degrades hydrogen peroxide into water and oxygen [52-53]. The activity of CAT in roots and leaves of $S$. babylonica declined during the whole experiment when compared with control. The decline in CAT activity was supposedly due to inhibition of enzyme synthesis or a change in assembly of enzyme subunits [53]. CAT is possibly a less efficient $\mathrm{H}_{2} \mathrm{O}_{2}$ scavenger than POD because of its low substrate affinity and is more sensitive to high Cd levels than SOD and POD as seen by the decline in CAT activity. In the present work, CAT activity decreased, suggesting that eliminating ROS by CAT was limited. Cd induced higher SOD and POD activities than CAT activity, indicating that SOD and POD provided a better defensive mechanism against Cd-induced oxidative damage in S. babylonica .

MDA formation is used as the general indicator of the extent of lipid peroxidation resulting from oxidative stress. The major consequence of Cd stress in plants is an enhanced production of high ROS, which are toxic to living systems and usually cause oxidative damage, inducing lipid peroxidation [54]. Data from the present work showed that the content of MDA increased significantly $(P<0.05)$ only at $100 \mu \mathrm{M} \mathrm{Cd}$ in roots and 50 and $100 \mu \mathrm{M} \mathrm{Cd}$ in leaves compared with controls, indicating that $\mathrm{Cd}$ indirectly leads to the production of superoxide radicals, resulting in increased lipid peroxidative products and oxidative stress in S. babylonica. Consequently, ROS-induced cellular damage induces local programmed cell death, which generally affects plant growth and development [55]. Some studies indicated that $\mathrm{Cd}$ toxicity was proven to induce the formation of various ROS and increase MDA content as a result of lipid peroxidation [21]. The present investigation showed that $\mathrm{Cd}$ exposure caused an increase in $\mathrm{O}_{2}{ }^{--}$and $\mathrm{H}_{2} \mathrm{O}_{2}$ concentrations associated with impaired integrity of the plasma membrane in S. babylonica [56].

The soluble protein content of $S$. babylonica increased under $\mathrm{Cd}$ stress in the present investigation. This can be explained by the fact that soluble protein is related to a variety of metabolic processes in cells, and $\mathrm{Cd}$ stress can induce related stress protein gene expression, which is a defensive mechanism of plants to environmental stress $[40,57]$.

\section{Conclusions}

Based on the information provided in this article, we conclude that:

1. S. babylonica can be considered as an efficient phytoextraction plant as it has considerable ability to accumulate $\mathrm{Cd}(\mathrm{Cd}$ concentration in shoot exceeding $0.01 \%(\mathrm{w} / \mathrm{w}))$. Cd can decrease the uptake and accumulation of Fe and $\mathrm{Mn}$ in S. babylonica.

2. In the presence of $\mathrm{Cd}$, the contents of $\mathrm{O}_{2} \cdot-$ and $\mathrm{H}_{2} \mathrm{O}_{2}$ of $S$. babylonica increase. The MDA content increases significantly. Meanwhile, $\mathrm{Cd}$ induces higher activities of SOD and POD than that of CAT, indicating that SOD and POD provide a better defensive mechanism against Cd-induced oxidative damage in S. babylonica.

3. The soluble protein content of $S$. babylonica increases under Cd stress. 


\section{Acknowledgements}

This project was supported by the Natural Science Foundation of Tianjin, China (grant No. 17JCYBJC22500). The authors wish to express their appreciation to the reviewers for their comments and suggestions.

\section{References}

1. PINTO A.P., MOTA A.M., DE VARENNES A., PINTO F.C. Influence of organic matter on the uptake of cadmium, zinc, copper and iron by Sorghum plants. Sci. Tot. Environ. 326, 239, 2004.

2. DAUD M.K., HE Q.L., MEI L., ALI B., ZHU S.J. Ultrastructural, metabolic and proteomic changes in leaves of upland cotton in response to cadmium stress. Chemosphere 120, 309, 2015.

3. CHOPPALA G., SAIFULLAH, BOLAN N., BIBI S., IQBAL M., RENGEL Z., KUNHIKRISHNAN A., ASHWATH N., OK Y.S. Cellular mechanisms in higher plants governing tolerance to cadmium toxicity. Crit. Rev. Plant Sci. 33, 374, 2014.

4. GE W., JIAO Y.Q., SUN B.L., QIN R., JIANG W.S., LIU D.H. Cadmium-mediated oxidative stress and ultrastructural changes in root cells of poplar cultivars. S. Afr. J. Bot. 83, 98, 2012.

5. CHANEY R.L. Plant uptake of inorganic waste constituents. In: PARR J.F., KLA J.M. (Eds.), Land treatment of hazardous waste. Noyes Data Corp, Park Ridge, NJ, 50, 1983.

6. WAN X.M., LEI M., YANG J.X. Two potential multi-metal hyperaccumulators found in four mining sites in Hunan Province, China. Catena 148, 67, 2017.

7. BAKER A.J.M., BROOKS R.R. Terrestrial higher plants which hyperaccumulate metallic elements - A review of their distribution, ecology and phytochemistry. Biorecovery 1, 81, 1989.

8. BAKER A.J.M., MCGRATH S.P., REEVES R.D., SMITH J.A.C. Metal hyperaccumulator plants: A review of the ecology and physiology of a biological resource for phytoremediation of metal-polluted soils. In: TERRY N., BAÑUELOS G.S. (Eds.). Phytoremediation of contaminated soil and water. CRC Press Inc., Boca Raton, FL, USA, 85, 2000.

9. BAKER A.J.M., WHITING S.N. In search of the holy grail - A further step in understanding metal hyperaccumulation? New Phytol. 155, 1, 2002.

10. JIAO Y.Q., GE W., QIN R., SUN B.L., JIANG W.S., LIU D.H. Influence of cadmium stress on growth, ultrastructure and antioxidative enzymes in Populus 2025. Fresen. Environ. Bull. 21, 1375, 2012.

11. DICKINSON N.M. Strategies for sustainable woodland on contaminated soils. Chemosphere 41, 259, 2000.

12. KACÁlKOVÁ L., TLUSTOŠ P., SZÁKOVÁ J. Phytoextraction of risk elements by willow and poplar trees. Int. J. Phytoremediat. 17, 414, 2015.

13. YANG J.L., LI K., ZHENG W., ZHANG H.Z., CAO X.D., LAN Y.X., YANG C.P., LI C.H. Characterization of early transcriptional responses to cadmium in the root and leaf of Cd-resistant Salix matsudana Koidz. BMC Genomics 16, 1, 2015.

14. ZOU J.H., WANG G., JI J., WANG J.Y., WU H.F., OU Y.J., LI B.B. Transcriptional, physiological and cytological analysis validated the roles of some key genes linked $\mathrm{Cd}$ stress in Salix matsudana Koidz. Environ. Experi. Bot. 134, 116, 2017.

15. GUO B.H., DAI S.X., WANG R.G., GUO J.K., DING Y.Z., XU Y.M. Combined effects of elevated $\mathrm{CO}_{2}$ and $\mathrm{Cd}$ contaminated soil on the growth, gas exchange, antioxidant defense, and $\mathrm{Cd}$ accumulation of poplars and willows. Environ. Exp. Bot. 115, 1, 2015.

16. DIMITRIOU I., ARONSSON P. Landfill leachate treatment with willows and poplars-efficiency and plant response. Waste Manag. 30, 2137, 2010.

17. LI H., ZHANG G.C., XIE H.C., LI K., ZHANG S.Y. The effects of the phenol concentrations on photosynthetic parameters of Salix babylonica L. Photosynthetica 53, 1, 2015.

18. YANG W.D., CHEN Y.T. Studies on cadmium uptake, accumulation and tolerance in Salix babylonica. J. Nanjing Forest. Univ. 33, 17, 2009.

19. WANG W.W., WU Y.J., AKBAR S., JIA X.Q., HE Z.H., TIAN X.J. Effect of heavy metals combined stress on growth and metals accumulation of three Salix species with different cutting position. Int. J. Phytoremediat. 18, 761, 2016.

20. SOLTI Á., SÁRVÁRI É., TÓTH B., MÉSZÁROS I., FODOR F., SZIGETI Z. Stress hardening under long-term cadmium treatment is correlated with the activation of antioxidative defence and iron acquisition of chloroplasts in Populus. Zeitschrift Für Naturforschung C 71, 323, 2016.

21. SANDBICHLER A.M., HÖCKNER M. Cadmium protection strategies - a hidden trade-off? Int. J. Mol. Sci. 17, 139, 2016.

22. YILDIZTUGAY E., OZFIDAN-KONAKCI C., KUCUKODUK M. Sphaerophysa kotschyana, an endemic species from central anatolia: antioxidant system responses under salt stress. J. Plant Res. 126, 729, 2013.

23. BAXTER A., MITTLER R., SUZUKI N. ROS as key players in plant stress signaling. J. Exp. Bot. 65, 1229, 2014.

24. BASHRI G., PRASAD S.M. Indole acetic acid modulates changes in growth, chlorophyll a fluorescence and antioxidant potential of trigonella foenum-graecum $\mathrm{L}$. grown under cadmium stress. Acta. Physiol. Plant 37, 49, 2015.

25. WU H.F., WANG J.Y., LI B.B., OU Y.J., JIANG W.S., LIU D.H., ZOU J.H. Characterisation of early responses to cadmium in roots of Salix matsudana Koidz. Toxico. Enviro. Chem. 2017. DOI: 10.1080/02772248.2017.1284850.

26. BICZAK R., SNIOSZEK M., TELESINSKI A., PAWLOWSKA B. Growth inhibition and efficiency of the antioxidant system in spring barley and common radish grown on soil polluted ionic liquids with iodide anions. Ecotox. Environ. Safe. 139, 463, 2017.

27. SIGAUD-KUTNER T.C.S., PINTO E., OKAMOTO O.K., LATORRE L.R., COLEPICOLO P. Changes in superoxide dismutase activity and photosynthetic pigment content during growth of marine phytoplankters in batch-cultures. Physiol. Plantarum 114, 566, 2002.

28. ZHANG S.S., ZHANG H.M., QIN R., JIANG W.S., LIU D.H. Cadmium induction of lipid peroxidation and effects on root tip cells and antioxidant enzyme activities in Vicia faba L. Ecotoxicology 18, 814, 2009.

29. ALAYAT A., SOUIKI L., GRARA N., DJEBAR M.R., BOUMEDRIS Z.E., BENOSMANE S., AMAMRA R., BERREBBAH H. Effects of cadmium on water content, soluble protein, proline changes and some antioxidant enzymes in wheat (Triticum durum desf.) leaves. Annu. Res. Rev. Biol. 4, 3835, 2014.

30. FATEMEH B., REZA K.H. Effect of cadmium on photosynthetic pigments, proline, soluble proteins and 
some antioxidant enzymes in lentil (Lens culinaris medik.) seedlings. J. Anim. Plant Sci. 5, 117, 2016.

31. ZHAO M.Z., LIU Z.L., CHEN W., CAI S.Y. Responses of Trifolium repens cv. rivendel seeds to cadmium stress in terms of electrolyte leakage and soluble protein content changes. Adv. Mater. Res. 955-959, 593, 2014.

32. PIPER C.S. Soil and plant analysis. Monograph. Waite Agricultural Research Institute, The University of Adelaide, Australia. 56, 263, 1942.

33. QIN R., JIAO Y.Q., ZHANG S.S., JIANG W.S., LIU D.H. Effects of aluminum on nucleoli in root tip cells and selected physiological and biochemical characters in Allium cepa var. agrogarum L. BMC Plant Biol. 10, 1, 2010.

34. HU L.X., LI H.Y., PANG H.C., FU J.M. Responses of antioxidant gene, protein and enzymes to salinity stress in two genotypes of perennial ryegrass (Lolium perenne) differing in salt tolerance. J. Plant Physiol. 169, 146, 2012.

35. ZHOU G., KONG Y., BI Y., LIANG H. Possible participation of active oxygen species in the induction of cyanide-resistant pathway at the initial senescence of tobacco callus. Russ. J. Plant Physl + 48, 588, 2001

36. BRADFORD M.M. A rapid and sensitive method for the quantification of microgram quantities of protein utilizing the principe of protein-dye binding. Anal. Biochem. 72, 278, 1976.

37. COURCHESNE F., TURMEL M., CLOUTIER-HURTEAU B., CONSTANTINEAU S., MUNRO L., LABRECQUE M. Phytoextraction of soil trace elements by willow during a phytoremediation trial in Southern Quebec, Canad. Int. J. Phytoremediat. 19, 545, 2017.

38. KERSTEN G., MAJESTIC B., QUIGLEY M. Phytoremediation of cadmium and lead-polluted watersheds. Ecotox. Environ. Safe. 137, 225, 2017.

39. LING T., JUN R., FANGKE Y. Effect of cadmium supply levels to cadmium accumulation by Salix. Int. J. Environ. Sci. Tech. 8, 493, 2011.

40. WU H.F., WANG J.Y, LI B.B., OU Y.J., WANG J.R., SHI Q.Y., JIANG W.S., LIU D.H., ZOU J.H. Salix matsudana Koidz tolerance mechanisms to cadmium: Uptake and accumulation, subcellular distribution, and chemical forms. Pol. J. Environ. Stud. 25, 1739, 2016.

41. DOS SANTOS UTMAZIAN M.N., WENZEL W.W. Cadmium and zinc accumulation in willow and poplar species grown on polluted soils. J. Plant Nutr. Soil Sci. 170, 265, 2007.

42. VAN DER ENT A., BAKER A.J.M., REEVES R.D., POLLARD A.J., SCHAT H. Hyperaccumulators of metal and metalloid trace elements: facts and fiction. Plant Soil 362, 319, 2013

43. DOS SANTOS UTMAZIAN M.N., WIESHAMME G., VEGA R., WENZEL W.W. Hydroponic screening for metal resistance and accumulation of cadmium and zinc in twenty clones of willows and poplars. Environ. Pollut. 148, 155, 2007.

44. SAIFULLAH S.N., BIBI S., AHMAD M., OK Y.S. Effectiveness of zinc application to minimize cadmium toxicity and accumulation in wheat (Triticum aestivum L.). Environ. Earth Sci. 71, 1663, 2014.
45. SHARMILA P., KUMARI P.K., SINGH K., PRASAD N.V.S.R.K., PARDHA-SARADHI P. Cadmium toxicityinduced proline accumulation is coupled to iron depletion. Protoplasma 254, 763, 2017

46. WANG L., HUANG X.C., MA F., SHIH-HSIN H., WU J.T., ZHU S.S. Environmental role of Rhizophagus irregularis in alleviating cadmium toxicity via improving the growth, micro- and macroelements uptake in Phragmites australis. Environ. Sci. Pollut. Res. Int. 24, 3593, 2017.

47. RAHMAN A., NAHAR K., HASANUZZAMAN M., FUJITA M. Manganese-induced cadmium stress tolerance in rice seedlings: Coordinated action of antioxidant defense, glyoxalase system and nutrient homeostasis. CR. Biol. 339, 462,2016

48. KOVÁCS K., KUZMANN E., VÉRTES A., LÉVAI L., CSEH E., FODOR F. Effect of cadmium on iron uptake in cucumber roots: A Mössbauer-spectroscopic Study. Plant Soil 327, 49, 2010.

49. SUN S., LI M., ZOU J.H., JIANG W.S., LIU D.H. Cadmium effects on mineral accumulation, antioxidant defence system and gas exchange in cucumber. Zemdirbyste-Agriculture 102, 193, 2015.

50. SIDHU G.P.S., SINGH H.P., BATISH D.R., KOHLI, $\mathrm{R}$. Tolerance and hyperaccumulation of cadmium by a wild, unpalatable herb Coronopus didymus (L.) Sm. (Brassicaceae). Ecotox. Environ. Safe. 135, 209, 2017.

51. ZOU J.H., YUE J.Y., ZHANG Z.G., JIANG W.S., LIU D.H. Effects of cadmium stress on root tip cells and some physiological indexes in Allium cepa var. agrogarum L. Acta Biol. Cracov. Bot. 54, 129, 2012.

52. LUSHCHAK V.I. Environmentally induced oxidative stress in aquatic animals. Aquat. Toxicol. 101, 13, 2011.

53. LI Y., ZHANG S.S., JIANG W.S., LIU D.H. Cadmium accumulation, activities of antioxidant enzymes, and malondialdehyde (MDA) content in Pistia stratiotes L. Environ. Sci. Pollut. Res. 20, 1117, 2013.

54. QURESHI M.I., D'AMICI G.M., FAGIONI M., RINALDUCCI S., ZOLLA L. Iron stabilizes thylakoid protein-pigment complexes in indian mustard during $\mathrm{Cd}$ phytoremediation as revealed by BN-SDS-PAGE and ESIMS/MS. J. Plant Physiol. 167, 761, 2010.

55. LUO C.S., LIANG J.R., LIN Q., LI C.X., BOWLER C., ANDERSON D.M., WANG P., WANG X.W., GAO Y.H. Cellular responses associated with ROS production and cell fate decision in early stress response to iron limitation in the diatom Thalassiosira Pseudonana. J. Proteome Res. 13, 5510,2014

56. SOUGUIR D., EL FERJANI E., LEDOIGT G., GOUPIL P. Transcript accumulation of stress-related genes in Vicia Faba roots under a short exposure to cadmium. Plant Biosyst. 149, 280, 2015.

57. XU Q.J., JIN X.C., WANG X.M., HU X.W., CHEN X.Q., YAN C.Z. Effects of different concentration Ammonium-n on Hydrilla verticillata antioxidant enzymes under Cd stress. Chin. J. Appl. Ecol. 18, 420, 2007. 